doi: 10.32620/oikit.2019.84.04

УДк 629.7 О. М. Застела, О. В. Трифонов, В. П. Водолажський

\title{
Моделювання процесу штампування діафрагми згинанням листової заготовки еластичним середовищем
}

\author{
Національний аерокосмічний університет ім. М.Є. Жуковського \\ «Харківський авіаційний інститут», \\ Харківський державний автодорожній коледж
}

\begin{abstract}
Метод штампування еластичним середовищем відомий давно і всюди. Про його подальше застосування і розвиток свідчать розробки, які дозволяють інтенсифікувати процес штампування еластичним інструментом. Серед таких напрямів вдосконалення особливо перспективним $\epsilon$ комп'ютерне моделювання процесу, яке дозволяє визначати енергосилові параметри процесу, поведінку матеріалу впродовж усього процесу, а також напружено-деформований стан заготовки, що дає можливість скоротити час надалі при розробленні процесів для типових деталей, а також значно понизити витрати матеріалів на проведення серій експериментів, скоротити трудомісткість і термін технологічної підготовки виробництва. Саме цей метод як найбільш прийнятний для удосконалення процесу штампування на нинішній стадії розвитку вітчизняного виробництва, розглянуто в роботі на прикладі згинанняфрормування листового матеріалу. Для вирішення завдань фрормоутворення, що здійснюються в цій роботі, найбільш раціональним є застосування варіаційного методу або ж методу МСЕ. Ці методи забезпечують отримання досить точних результатів, проте перевагою MCE $€$ його велика застосовність у різних комп'ютерних програмних продуктах, таких, як Nastran, Ansys, Katy та ін., що дозволяє оптимізувати процес отримання даних скороченням часу розрахунку, а також найбільш оптимальною можливістю вносити зміни і коригування в процес без необхідності витрати час на ручний перерахунок.

Ключові слова: моделювання процесу штампування, листова заготовка, еластичне передавальне середовище, напружено-деформований стан.
\end{abstract}

Одне 3 найбільш важливих місць серед процесів штампування еластичним середовищем займають процеси згинання і згинання-формування, вживані для виготовлення деталей каркаса з листа. Відмітною особливістю процесу згинання-формування $€$ вільна взаємодія інструменту (еластичне середовище) з плоскою заготовкою, що спирається на жорстку опору, інструмент, що $є$ носієм форми деталі. Вільне згинання-фрормування еластичним середовищем має великі технологічні можливості і граничну простоту змінного інструменту.

Основні марки поліуретанів мають твердість за Шором А в інтервалі $65 . .98$, опором розриву в інтервалі $27 \ldots 35$ МПа, подовженням при розриві $230 \ldots 700 \%$, ударною в'язкістю - 2...12 МПа. При цьому стійкість проти старіння у поліуретанових еластомерів у декілька сотень разів вище, ніж у натурального і синтетичного каучуку. У вітчизняному листоштампувальному виробництві для процесів згинання-фрормування найчастіше застосовують поліуретан СКУ-7Л. Деталі, виготовлені із застосуванням цього поліуретану, мають високу якість, поверхню без подряпин і задирок.

До основних параметрів процесу згинання еластичним середовищем відносяться зусилля деформації, потрібний деформувальний тиск, глибина згинання, необхідна твердість і міцність поліуретану, а також параметри, що визначають точність процесу. 
Плоска заготовка, піддана згинанню, стає під дією зусиль з боку пуансона і еластичної матриці просторово зігнутою деталлю. Згинанням виготовляють найрізноманітніші деталі, воно може бути одно -, двох - і чотирьохкутовим в одній або декількох площинах, може поєднуватися одночасно з відрізанням, вирубуванням і пробиванням. На відміну від згинання в жорстких штампах згинання в штампах 3 еластичною матрицею дозволяє отримати деталі складнішої конфрігурації за один перехід.

На відміну від згинання на жорсткій матриці, згинання на еластичній матриці супроводжується деформацією останньої спільно із заготовкою (рисунок 1).

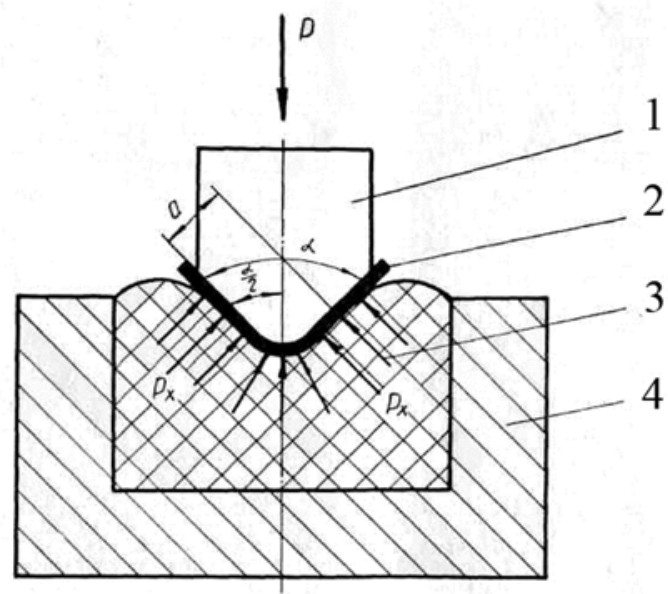

Рис. 1 - Схема згинання деталі на вільній поверхні еластичної матриці 1 - пуансон, 2 - деталь у момент закінчення гнуття, 3 - еластична матриця, 4 - контейнер

Зусилля

штампування еластичним середовищем містить три складові: зусилля деформації заготовки, зусилля деформації еластичного інструменту i сумарну силу тертя еластичного середовища і інструменту. Зусилля, необхідне для деформації заготовки, визначається 3 рівності моментів внутрішніх і зовнішніх сил: $M_{в н}=M_{3}$, 3 урахуванням значення величини моменту опору волокна, ширини заготовки $B$, товщини матеріалу заготовки $s_{0}$ і плеча $a$, яке пропорційне товщині формованої заготовки, куту згинання $\alpha$, жорсткості еластичної подушки і залежить від радіусу згинання $r$

$$
M_{3}=P_{x} \cdot a,
$$

де $P_{X}$ - реакція, що діє з боку еластичної матриці на заготовку.

$$
a=\frac{\alpha}{2} \cdot s_{0} \cdot K \cdot \frac{r+1}{r},
$$

де $K$ - коефіцієнт жорсткості еластичної матриці.

Вираження реакції $P_{X}$ через питомий тиск при згинанні в штампі 3 відкритим об'ємом недоцільне, оскільки воно розподіляється по площі заготовки нерівномірно. Тоді загальне зусилля згинання для штампа з відкритим об'ємом [1]:

$$
\begin{gathered}
P=\frac{P_{X} \cdot B}{\sin \frac{\alpha}{2}} ; \\
P=\frac{s_{0} \cdot\left(1.5+\varepsilon_{b}\right) \cdot \sigma_{b}}{6 \cdot \sin \frac{\alpha}{2} \cdot K \cdot \frac{r+1}{r}}
\end{gathered}
$$


де $\varepsilon_{6}$ - відносне подовження матеріалу заготовки у момент початку утворення шийки. При зменшенні кута згинання $\alpha$ зменшується плече $a$, а отже, збільшується зусилля, необхідне для згинання.

Для визначення величин деформувальних тисків на межі еластомерзаготовка при формоутворенні деталей з листа еластичними середовищами розглядають характерні процеси згинання-фрормування і вільного згинання, що відповідають видам напруженого стану (рис. 2).

Істинний тиск $q_{i}$, переданий з боку еластичного середовища матеріалу, що деформується, визначається як сума двох компонент тисків :

$$
q_{i}=q_{2 c} \pm q_{e}
$$

де $q_{2 c}$ - гідростатичний тиск, що передається на заготовку, в припущенні, що еластичне середовище поводиться як ньютонівська рідина; $q_{e}$ - компонент тиску, контакту, що додається або знімається з даної ділянки, з оброблюваним матеріалом, за рахунок напруженого стану в самому середовищі, що викликається деформацією.
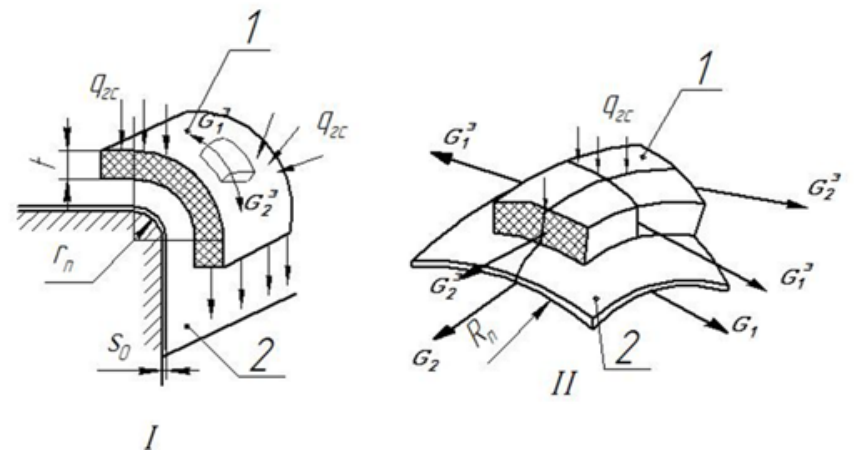

Рис. 2 - Схеми для аналізу характерних випадків контактної взаємодії еластичної деформувального середовища (1) i заготовки (2) при визначенні істинних контактних навантажень, діючих на оброблюваний матеріал

I - вільне гнуття по жорсткому пуансону;

II - фрормоутворення рельєфу подвійної кривизни по жорсткому пуансону
Позитивний знак при $q_{e}$ відповідає умові, коли напруження, що діють в елементі оболонки, і напрям гідростатичного тиску збігаються, негативний знак відповідає умові, коли напрям діючого напруження і напрям дії гідростатичного тиску $\epsilon$ протилежними.

Враховуючи, що зміна істинного напруження залежно від відносного подовження підпорядковується степеневому закону $\sigma_{i}=B \varepsilon_{i}^{n}$ (де $B$ і $n-$ константи еластомеру), компонент тиску $q_{e}$ для різних випадків буде таким [2].

Для випадку вільного згинання по жорсткому пуансону (рис. 2, I), де радіус закруглення жорсткого пуансона $r_{n}$, а товщина шару еластомеру, що деформується $t$ :

$$
q_{e}=q_{z c}+\frac{\sigma_{i} t}{r_{n}+s_{0}+\frac{t}{2}}=q_{z c}+\frac{B \varepsilon_{i}^{n} t}{r_{n}+s_{0}+\frac{t}{2}} .
$$

Для випадку формоутворення рельєфу подвійної кривизни по жорсткому пуансону (рис. 2, II): 


$$
q_{e}=q_{z c}+\frac{2 B \varepsilon_{i}^{n}\left(R_{\Pi}+s_{0}+\frac{t}{2}\right) t}{\left(R_{\Pi}+s_{0}^{2}\right)^{2}} .
$$

Гідростатичний тиск знаходять з умови рівності моментів внутрішніх і зовнішніх сил $M_{в н}=M_{3}$. На рисунку 3 показано схему дії сил і позначення геометричних параметрів при згинанні прямолінійного борта. Для прямолінійного борту ця формула має вигляд

$$
q_{2 c}=\frac{3 \sigma_{B} R s_{0}^{2}+\Pi s_{0}^{3}}{6 R(A-R \phi)^{2}},
$$

де $\phi$ - кут згинання, $R$ - радіус згинання в нейтральному шарі, $\boldsymbol{A}$ - величина, що знаходять за формулою

$$
A=a+R \phi .
$$

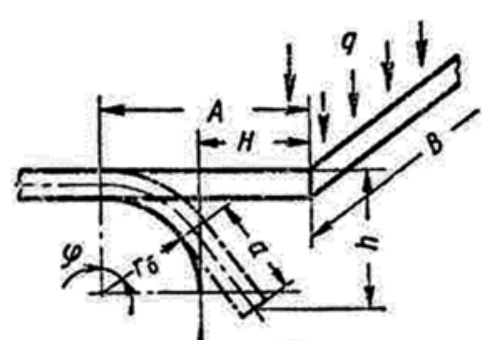

Рис. 3 - Геометричні параметри при згинанні прямолінійного борта

Проте, якщо для прямолінійного борту формула визначення гідростатичного тиску не складна для розрахунку, то при згинанні складніших деталей з криволінійними бортами і стінками формули являють собою складні математичні залежності. Тому для проведення швидких розрахунків для деталей 3 опуклими або увігнутими бортами застосовують спрощену фрормулу [3]:

$$
q_{2 c}=q_{1}+q_{2}=\frac{\sigma_{B} \cdot s_{0}^{2}}{2 \cdot\left(H-r_{n}-s_{0}\right)^{2}}+\frac{\sigma_{B} \cdot s_{0}}{R_{\Pi}} .
$$

Тут $q_{1}$ - тиск, викликаний вигином плоского

борта навколо ребра оснащення, а $q_{2}$ - тиск, викликаний тангенціальними пластичними деформаціями розтягування i стискування. 3 аналізу залежностей видно, що потрібні для формоутворення тиски тим більше, чим вище опір деформації штампованого матеріалу, чим більше товщини заготовки, висота борта і чим менше радіусу борта в плані.

Пластична деформація завжди супроводжується пружною деформацією, яка зникає після зняття навантаження. Отже, форма і розміри деталі відрізняються від форми і розмірів відповідних контактуючих поверхонь штампувального оснащення. Для виготовлення деталей із заданими кутами $\mathrm{i}$ радіусами згинання необхідно враховувати пружну віддачу (пружинення) матеріалу деталі, що виявляється в зміні значень кутів і радіусів деталей після зняття навантаження. Розрахунок пружної віддачі листових матеріалів при згинанні можна робити за формулами або діаграмами, побудованими за цими формулами. Розрахунок кута пружинення практично при будь-яких радіусах згинання визначають за формулою [4] 


$$
\gamma=\frac{3 K}{(2+n) E}\left(\frac{2 r_{\sigma}}{s_{0}}+1\right)^{1-n} \phi,
$$

де $K, n$ - постійні коефіцієнти для цього матеріалу, тобто зміцнення, що характеризують інтенсивність.

При невеликих відносних радіусах згинання ( $r<10)$, які зазвичай мають деталі, кут пружинення можна розрахувати за наближеною фрормулою [5]:

$$
\gamma=\frac{3 \sigma_{B}}{E}\left(\frac{r_{\sigma}}{s_{0}}+1\right)^{1-n} \phi .
$$

У зв'язку з пружиненням необхідно коригувати робочі частини штампа або вручну доводити деталі. Це неминуче через те, що відмінність фрорм деталей і чинників, що роблять вплив на величину пружинення, не дозволяє знайти надійні формули для усіх випадків згинання. При невеликих відносних радіусах згинання кути і радіуси згинальних оправок будуть однаковими:

У зв'язку 3 пружиненням

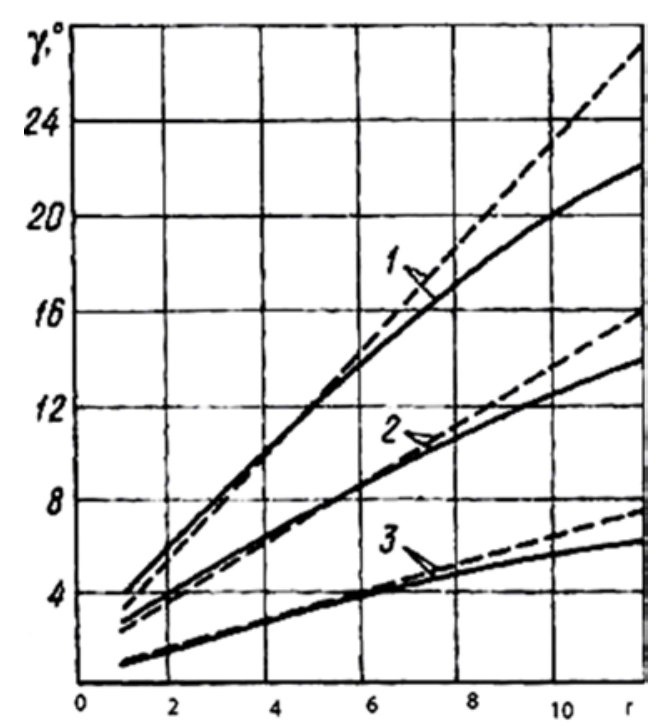
необхідно коригувати робочі частини штампа або вручну доводити деталі. Це є неминучим через те, що відмінність форм деталей і чинників, що роблять вплив на величину пружинения, не дозволяє знайти надійні формули для усіх випадків згинання. При невеликих відносних радіусах згинання кути і радіуси згинальних оправок будуть однаковими:

$$
\begin{gathered}
\phi_{2}=\left[1+\frac{3 \sigma_{B}}{E}\left(\frac{r_{\sigma}}{s_{0}}+\frac{1}{2}\right)\right] \phi ; \\
r=\frac{1}{r_{\sigma}+0.5}+\frac{3 \sigma_{b}}{E}-\frac{s_{0}}{2} .
\end{gathered}
$$

1 - МА2-1, S=0.8 мм, 2 - Д16АТ, $\mathrm{S}=1.4$ мм, 3 - Д16АМ, S=1.2 мм, розрахунок за точною формулоюі;

- -- - -за наближеною фрормулою

Рис. 4 - Зміна кута пружинення залежно від радіуса згинання для різних матеріалів
При згинанні деталей за великим радіусом $\left(r_{\sigma} / s_{0}>10\right)$ коригування форми згинального пуансона на пружинення має здійснюватися не лише за кутом згинання, але і за радіусом. При малих відносних радіусах згинання ( $\left.r_{\sigma} / s_{0}<5\right)$, а також при виготовленні деталей, що не потребують високої точності, коригування згинального оснащення здійснюється тільки на кут пружинення, оскільки радіус згинання змінюється трохи. 
На рисунку 4 показано графік зміни кута пружинення залежно від радіусу згинання для різних матеріалів при розрахунках, проведених за точними і наближеними формулами. Зі збільшенням радіуса згинання збіжність експериментальних i розрахункових значень кутів пружинения зростає.

Встановлено, що кут пружинення листових матеріалів не залежить ні від марки матеріалу еластичної матриці (гума, поліуретан), ні від їі твердості за умови, що процес згинання заготовки за радіусом оснащення здійснюється повністю.

У процесі згинання-фрормування важливий вплив на точність деталі має стоншування матеріалу. Найбільше стоншування заготовка отримує в зоні згинання, де виникає найбільше напруження в процесі фрормоутворення. Величину стоншування в зоні згинання розраховують за формулою [6]

$$
\Delta s=\frac{s_{0}^{3}}{4\left(2 r_{0}-s_{0}\right)^{2}} .
$$

3 формули видно, що при $r_{0} \rightarrow 0$ має місце найбільша зміна товщини матеріалу, яка наближається до значення $0.25 s_{0}$. Зі збільшенням радіуса згинання стоншування матеріалу зменшується.

Метод скінченних елементів (MCE) зводиться до апроксимації суцільного середовища з нескінченним числом степенів вільності до сукупності елементів 3 кінцевим числом степенів вільності [6]. Метод $€$ одним 3 найефективніших і точніших.

Позитивними якостями МCE $€$ гнучкість і різноманітність сіток, стандартні прийоми побудови дискретних завдань для довільних областей, простота обліку природних крайових умов і т.д. Крім того, математичний аналіз МСE $€$ простішим, його методи застосовані до ширшого класу початкових завдань, а оцінки похибок наближених рішень, як правило, виходять при менш жорстких обмеженнях.

У цій роботі як інструмент використано МСE, покладений в основи програми Ansys. Окрім методу MCE в роботі наведені розрахунки, основані на інженерному методі. Ці розрахунки не потребують великих часових витрат, проте дозволяють перевірити отримані дані і визначити можливі похибки, що дозволить забезпечити найбільш точне розв'язання задачі.

Мета досліджень у даній роботі полягає в отриманні математичної моделі, яка відображає фрізику згинання листової деталі, для подальшого дослідження впливу геометричних і фрізико-механічних параметрів технологічного процесу на якість отриманої деталі довільної геометрії. Завдання визначення НДС заготовки при пружно-пластичній деформації, яка $\epsilon$ характерною для усіх процесів згинання-фрормування, в загальному випадку $є$ тривимірною, геометрично і фрізично нелінійною. Така постановка завдання призводить до виникнення серйозних ускладнень, пов'язаних зі складністю і трудомісткістю вирішення. Спрощення і прискорення процесу вирішення можливе за рахунок звуження області дослідження, зменшення мірної завдання, максимально можливої лінеаризації фрізико-механічних процесів і геометричних граничних умов, використання поетапного рішення. Проте прийняті допущення не мають істотно спотворювати дійсну фізику процесу. Для оцінювання рівня 
відповідності модельного процесу натурному необхідно потім провести порівняння результатів іззаздалегідь вибраними критеріями.

При побудові математичної моделі операції згинання-фрормування еластичним середовищем по жорсткій матриці були використані такі припущення: тиск з боку еластичного середовища на заготовку гідростатичний; напруження по нормалі до товщини оболонки (в силу їх малості порівняно 3 напруженням, що діє в площині листа) приймається таким, що дорівнює нулю; в силу малості відносної товщини стінки формованої деталі

Внаслідок малості деформацій елементів оснащення (матриця) порівняно 3 деформаціями заготовки 3 метою спрощення розрахунку і скорочення машинного часу деформаціями елементів оснащення можна нехтувати. У зв'язку 3 цим матрицю приймають абсолютно твердим тілом. Механічні параметри матеріалу заготовки визначають за білінійним законом зміцнення, теплові ефекти не враховують.

При реалізації математичної моделі була написана і відлагоджена програма для ПЕВМ, що дозволяє методом послідовних наближень визначити НДС фрормованої заготовки на кожному кроці навантаження аж до моменту появи однієї з можливих (на цій операції) технологічних відмов деформаційного типу.

На основі безмоментної теорії тонкостінних оболонок розроблено математичну модель операції штампування деталей 3 листа еластичним середовищем по жорсткій матриці, для реалізації якої в системі комп'ютерного моделювання складені алгоритм і програма розрахунку НДС фрормованої заготовки.

Застосування пропонованої математичної моделі дає можливість не лише проектувати операції згинання-формування еластичним середовищем, але і вирішувати завдання, пов'язані з її оптимізацією. Крім того, створюються передумови для оцінювання технологічності деталі, що виготовляється, ще на стадії проектування конструкції.

Опис завдання: Визначення напруження, деформацій, сил деформації, стоншування, пружинення при згинанні-фрормовці деталі з листової заготовки при квазістатичній пружно-пластичній деформації заготовки в

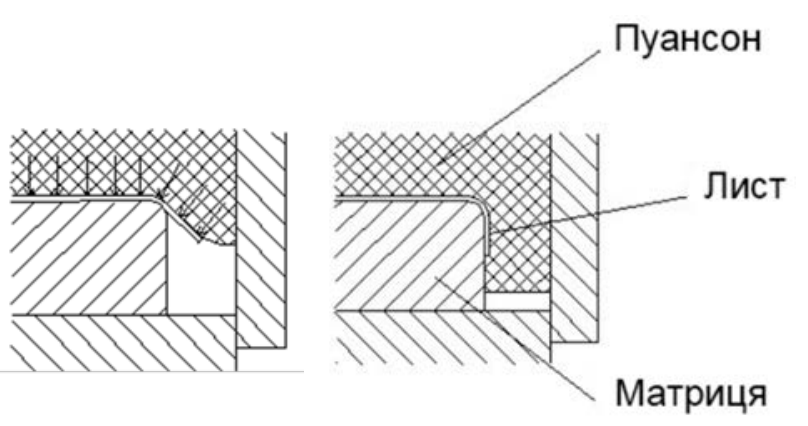

a

б

Рис. 5 - Схема дії сил при згинанні борта а - начальна стадія; б - кінцева стадія інструментальному штампі при відомих геометричних параметрах, властивостях матеріалу, початкових і граничних умовах.

Для дослідження було вибрано деталь типу діафрагми. В процесі штампування для отримання остаточної форми деталі здійснюють згинання бортів. Схему процесу дії сил для згинання показано на рисунку 5. Вирішення завдань проводять у два етапи, в першому з яких буде здійснено

безпосередньо формоутворення, а в другому розглянуто залишкові явища процесу, в даному випадку пружинення. Таке розмежування пов'язано із специфікою MCE системи ANSYS/LS - DYNA. Це обумовлено істотною фрізичною і геометричною нелінійністю процесу згинання-формування, що 
характеризується протяжними контактними поверхнями і великими пластичними деформаціями. Як матеріал для заготовки був вибраний матеріал Д16АМ. Необхідні для вирішення завдання фрізико-механічні властивості наведені в таблиці 1.

Таблиця 1 - Значення фрізико-механічних параметрів матеріалу заготовки

\begin{tabular}{|c|c|c|c|c|}
\hline $\begin{array}{l}\text { Коефріцієнт } \\
\text { Пуассона } \mu\end{array}$ & $\begin{array}{c}\text { Межа } \\
\text { плинності } \\
\sigma_{T}, \text { МПа }\end{array}$ & $\begin{array}{c}\text { Модуль } \\
\text { гнучкості E, } \\
\text { МПа }\end{array}$ & $\begin{array}{c}\text { Модуль } \\
\text { зміцнення П, } \\
\text { МПа }\end{array}$ & $\begin{array}{c}\text { Питома вага } \rho, \\
\text { кг/м }{ }^{3}\end{array}$ \\
\hline 0,34 & 108 & 72000 & 480 & 2750 \\
\hline
\end{tabular}

Матеріал матриці Сталь 20 має такі характеристики: $\sigma_{T}=236 \mathrm{MПа,}$ $\mu=0.29, \rho=7859 \kappa г / \mathrm{M}^{3}, E=72000 \mathrm{MПа.}$

Для пуансона як матеріал для еластичного середовища вибраний поліуретан СКУ-7Л з густиною $\rho=1250$ кг/м³ та модулем при розтягуванні $300 \%$, що дорівнює 7 МПа.

Розрахункова модель утворює систему "Матриця -

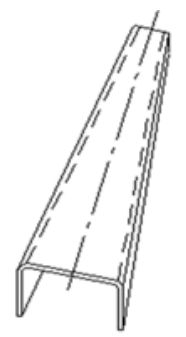

Рис. 6 - Ескіз діафрагми заготовка - пуансон". Геометричними параметрами, які описують елементи наведеної системи, є такі: для матриці радіус скруглення робочої кромки, висота, габаритні розміри; для пуансона - висота, ширина і довжина еластичної подушки; для заготовки - товщина і розміри листа. Значення геометричних параметрів варіюється залежно від постановки завдання і зміни кута згинання.

При згинанні-формовці діафрагми необхідно здійснити згинання двох бортів деталі. Проте деталь $\epsilon$ осесиметричною. і для скорочення часу розрахунку досить розглянути половину формованої деталі.

Ескіз деталі показано на рисунку 6.

Початкова заготовки для діафрагми - лист з розмірами $140 \times 28010^{-3} \mathrm{~m} \mathrm{i}$ завтовшки 1,2 $10^{-3} \mathrm{M}$.

Схема процесу згинання борта діафрагми показана на рисунку 7, а в таблиці 2 наведені значення усіх необхідних геометричних параметрів системи для побудови геометрії процесу.

Таблиця 2 - Геометричні параметри системи для діафрагми

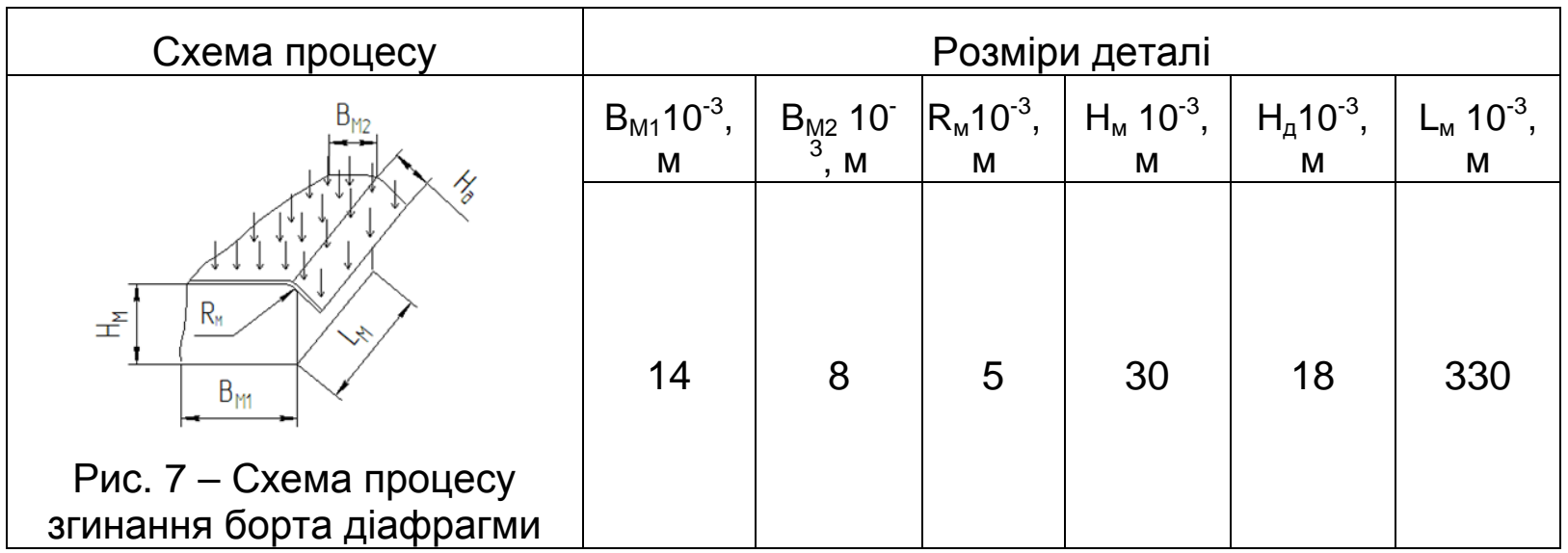


де, $\mathrm{B}_{\mathrm{M} 1}, \mathrm{~B}_{\mathrm{M} 2}$ - половина ширини матриці для двох сторін діафрагми;

$\mathrm{R}_{\mathrm{M}}$ - радіус скруглення робочої кромки матриці;

$\mathrm{H}_{\mathrm{M}}$ - висота матриці; $\mathrm{L}_{\mathrm{M}}$ - довжина матриці; $\mathrm{H}_{\mathrm{A}}$ - висота борта, що відгинається.

Дискретизація усіх елементів наведеної системи в результаті заздалегідь вибраної проводиться оболонковими елементами. Точність результату, який виходить за допомогою МСE, залежить від характерного розміру і фрорми елемента. Розбиття ведеться з урахуванням необхідності отримання дрібнішої сітки в місцях, де можливе утворення дефектів, і більшою - по всій іншій області.

Для випадку формоутворення деталі типу діафрагми розглядається тільки половина моделі для скорочення розрахункового часу. Тому необхідно задати обмеження на ті вузли, які знаходяться на межі симетрії, і заборонити один поступальний і два обертальних ступеня вільностідля забезпечення умов осьової симетрії.

На рисунку 8 показаний розподіл напруження по заготовці на стадії формоутворення діафрагми. На початковому етапі максимальне напруження буде сконцентровано в зоні згинання, а потім його значення зменшиться і перерозподілиться по усьому борту, при цьому максимум так і залишиться в зоні згинання. Виходячи з отриманих даних можна зробити висновок про те, що максимальне напруження, що виникає в матеріалі протягом всього часу процеса, набагато менше межі міцності цього матеріалу, а отже, деталь не матиме розривів як по усій площині, так і в області згинання, найбільш небезпечній зоні.
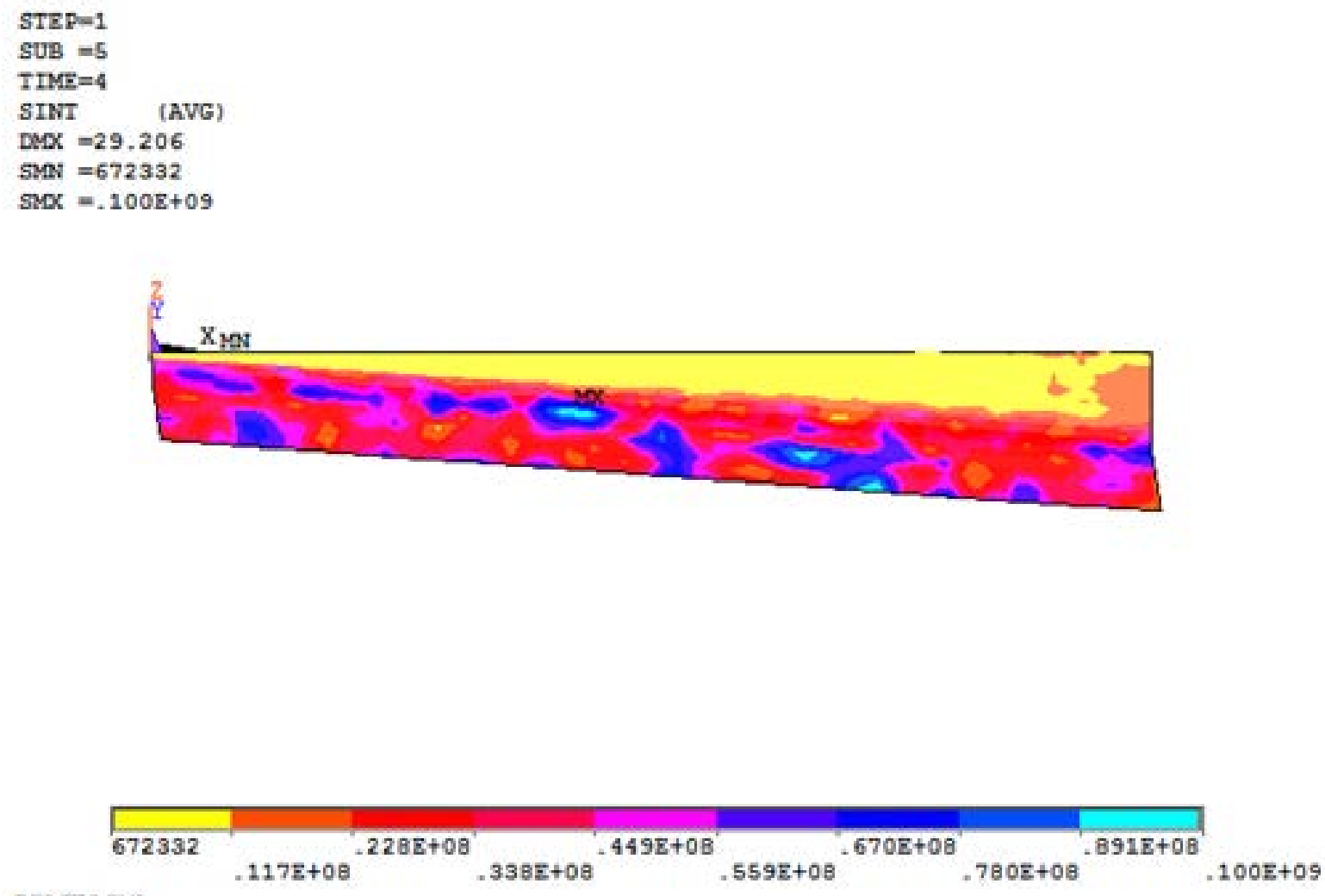

DIAFRAGEA

Рис. 8 - Розподіл напружень по заготовці на кінцевому кроці вантаження 
На рисунку 9 показано графрік напружень і інтенсивності напружень за часом для координат по висоті борта. 3 графріка видно, що максимальне напруження виникає до кінця процесу, коли починається стадія прилягання борта до поверхні матриці.

Виходячи з отриманого напруження можна побудувати графрік залежності деформацій від часу для зони згинання (рисунок 10). На відміну від зони борта в зоні згинання деформація починається відразу на початкових етапах, а в середині процесу сповільнюється, це відповідає моменту початку прилягання борту до поверхні матриці .

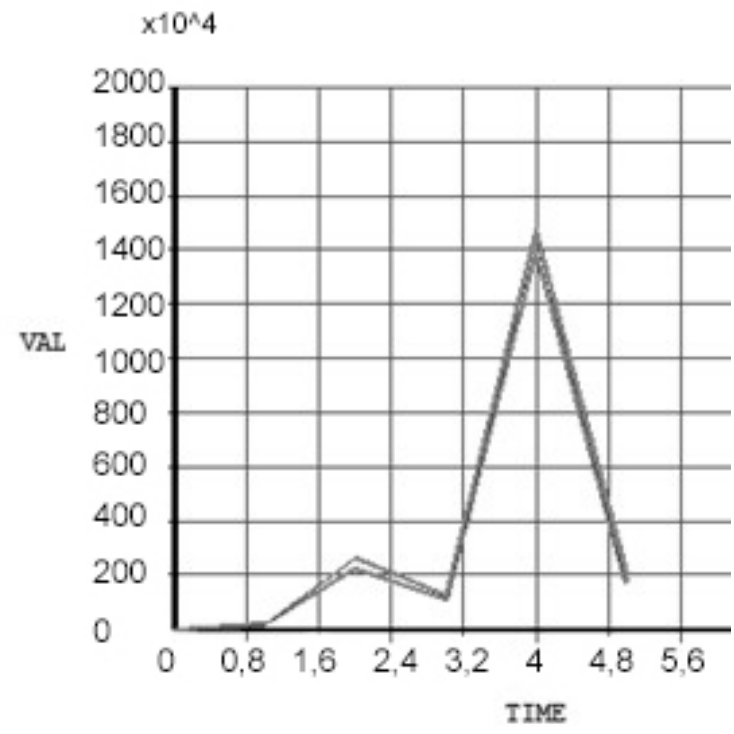

Рис. 9 - Графрік залежності величини і інтенсивності напружень за часом

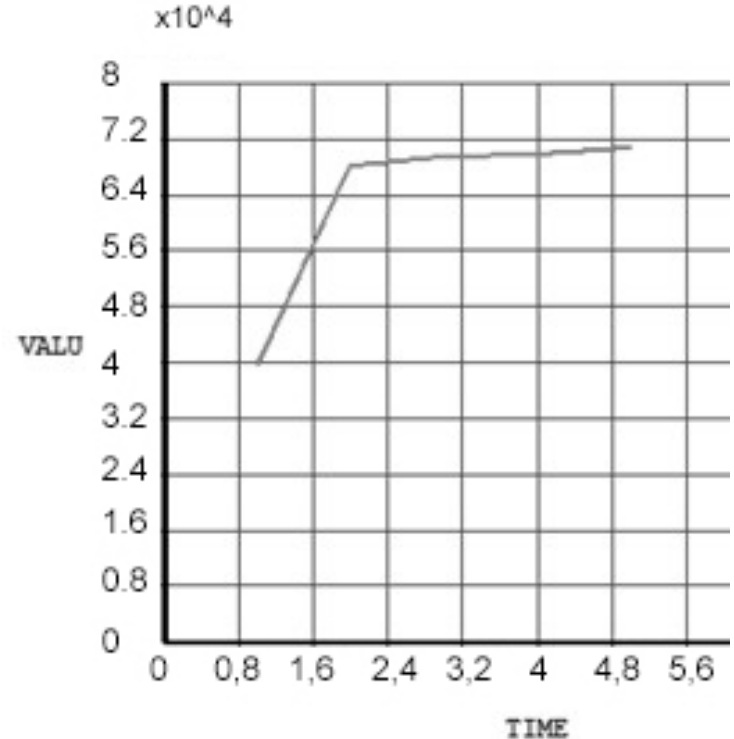

Рис. 10 - Граффік залежності величини деформацій за часом

3 отриманих даних видно, що розподіл напружень нерівномірний, тому для подальшого аналізу деталь умовно розділяється на три зони (рис. 11) : стінку, зону, де напруження буде мінімальним, зону 1 або зону згинання, де деталь отримує максимальні деформації і

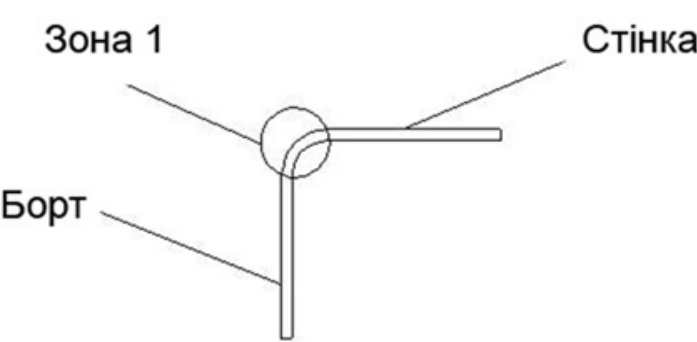

Рис. 11 - Зони деформації напруження, а також зону борта. Для наочного подання картини напружень по зонах деталі будується графрік залежності еквівалентних напружень по ширині заготовки, розбитої на зони (рис. 12). 3 графріка видно, що найбільш напруженою $є$ зона згинання, при підході до якої напруження стрибкоподібно зростає, а при перетині її значно зменшується. 


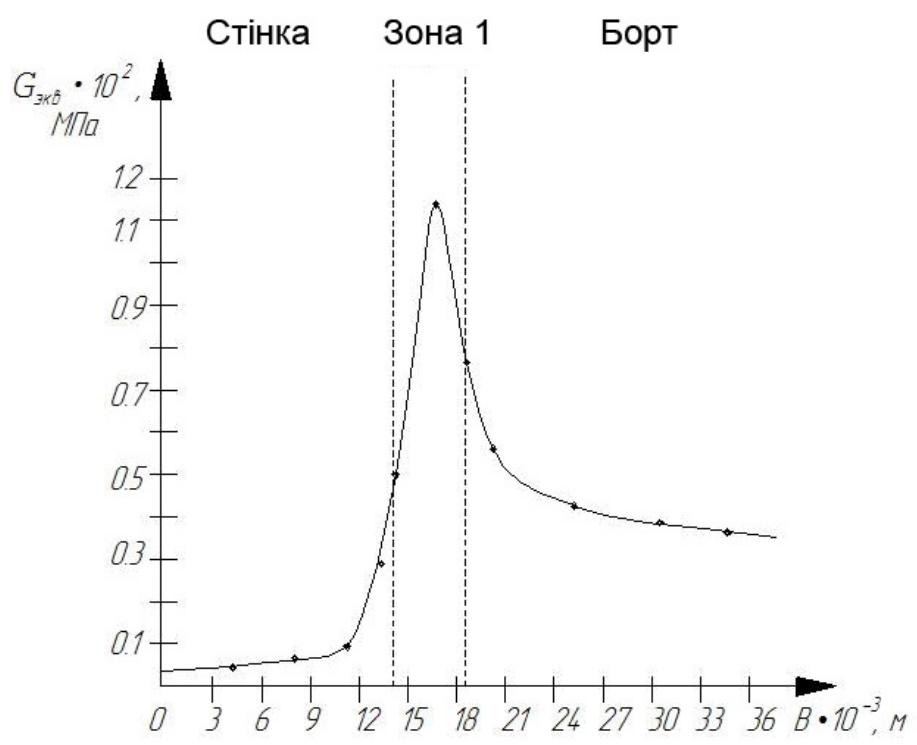

Рис. 12 - Графік залежності величини деформацій по зонах деталі

Крім того, на цьому етапі проводять аналіз розподілу товщини по ширині деталі, тобто знаходження максимального стоншування і найбільш небезпечної зони штампування. Виходячи з отриманих результатів можна зробити висновок про те, що найбільш небезпечна зона - зона згинання, проте отримане стоншування знаходиться в допустимих межах, хоча і значення по довжині зони розподіляється нерівномірно, що можна пояснити специфікою геометрії деталі.

Для подальшого визначення величини потрібного для деформації тиску необхідно отримати розподіл внутрішніх моментів і знайти його максимальне значення. Максимальне значення доводиться на зону згинання і становить $28 H \cdot M$. Після закінчення моделювання можна подивитися як змінилося напруження в процесі пружинення (рисунок 13). 3 рисунка видно, що після розвантаження напружень змінилися на один порядок.
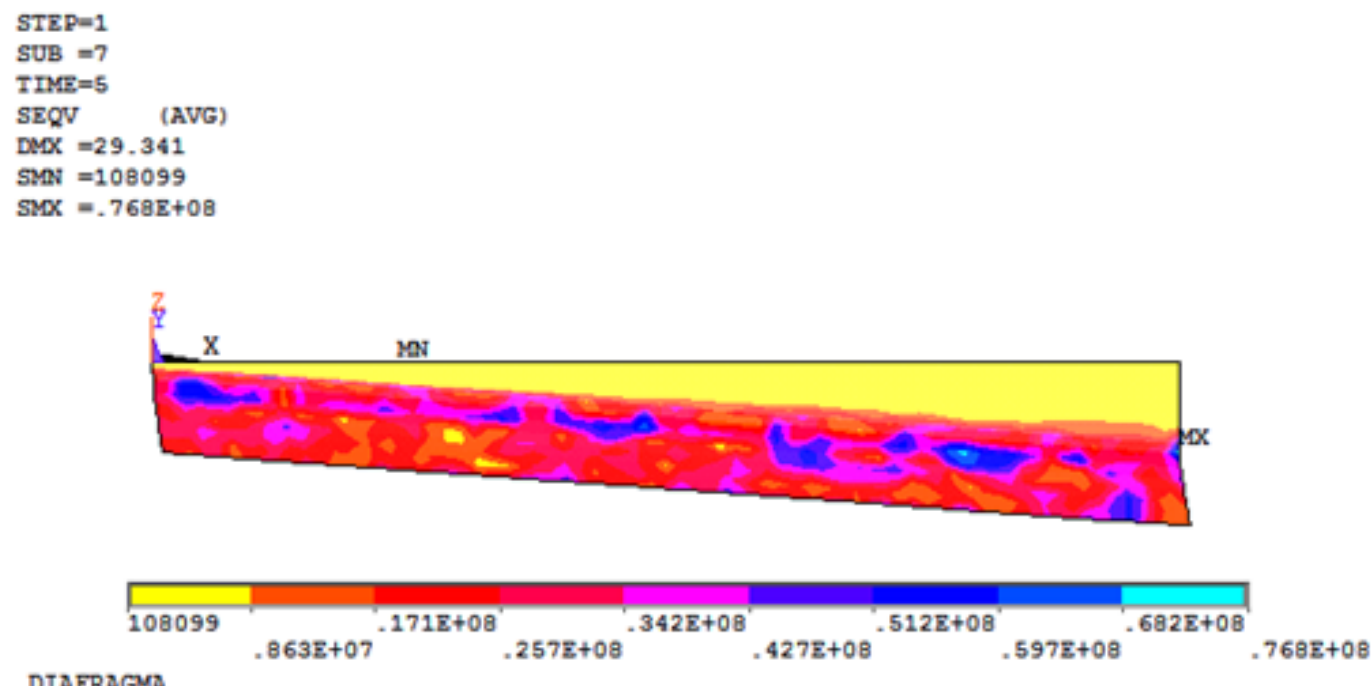

Рис. 13 - Розподіл напружень по деталі після розвантаження 
Проте для того, щоб визначити кут пружинення, який надалі буде найважливішим чинником при коригуванні геометрії матриці, необхідно розглянути ті переміщення вузлів, які

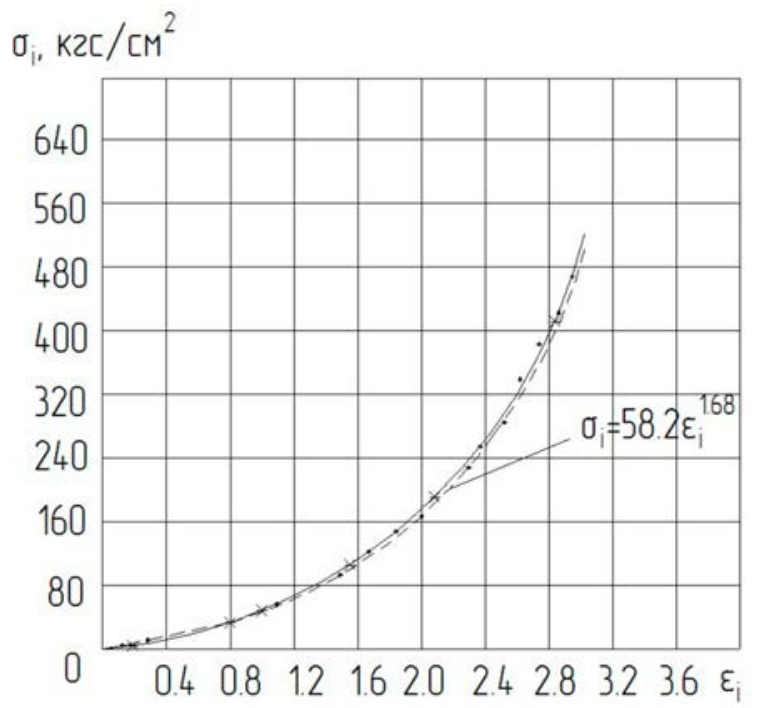

Рис. 14 - Діаграма зміни напружень від міри істинної деформації для поліуретану СКУ-7Л сталися під час розвантаження, зміну геометрії деталі. 3 отриманих даних видно, що найбільший приріст становить $0.085 \cdot 10^{-3}$ м. Враховуючи, що згинання велося на кут $90^{\circ}$, то через вузол 3 максимальним приростом можна провести умовний прямокутний трикутник. Тоді

$\sin \phi=\Delta y, \quad a \phi=\arcsin (\Delta y)=$ $=\arcsin (0.085) \approx 4.48^{\circ}$

Таким чином, коригувальний кут пружинення становить $4^{\circ}$.

1. Розрахунок величини потрібного тиску з боку еластичного середовища

При розрахунку потрібного тиску еластичного середовища для діафрагми за спрощеною фрормулою другий доданок не враховується

$$
q_{\text {гсd1 }}=\frac{236 \cdot 10^{6} \cdot 1.2^{2} \cdot 10^{-6}}{2 \cdot(18-5-1.2)^{2} \cdot 10^{-6}}=1.22 \mathrm{M \Pi a} \text {. }
$$

Точний розрахунок гідростатичного тиску для діафрагми проводять за формулою (8)

$$
q_{\text {гсд1 }}=\frac{3 \cdot 236 \cdot 10^{6} \cdot 0.0056 \cdot 0.0012^{2}+480 \cdot 10^{6} \cdot 0,0012^{3}}{6 \cdot 0,0056 \cdot\left(0.023-0.0056 \cdot \frac{3.14}{2}\right)^{2}}=0.96 \mathrm{M \Pi} .
$$

Тиск розрахований за спрощеною і точною формулою має розбіжність від 2 до 17\%, що допустимо для практичних цілей.

2. Розрахунок додаткової компоненти тиску від деформації шару еластомера навколо пуансона

Для випадку згинання бортів діафрагми по жорсткій матриці застосовують формулу 6 для розрахунку додаткової компоненти тиску. Для знаходження компоненти інтенсивності напружень $\sigma_{i}^{e}$ використовують апроксимацію діаграми інтенсивності напружень у вигляді степеневої залежності $\sigma_{i}^{e}=B \cdot \varepsilon_{i}^{n}$ [2]. На рисунку 14 показано діаграму зміни напружень для поліуретану СКУ-7Л від міри інтенсивності деформації $\varepsilon_{i}$ при лінійному розтягуванні. Для діафрагми $\varepsilon_{i}$ розраховують за фрормулою $\varepsilon_{\text {max }}=s_{0} / 2 r_{c p}=1 / 2 \bar{r}$, 
При

$$
\varepsilon_{\partial 1}=\frac{0.0012}{2 \cdot 0.0056}=0.107
$$

Тоді

$$
\begin{aligned}
\varepsilon_{\partial 1} & =0.107 \\
\sigma_{\partial 1} & =58.2 \cdot 0.107^{1,68}=0.14 \text { MПa } .
\end{aligned}
$$

$$
q_{\text {до }}=\frac{1.36 \cdot 7}{0,5+0,12+\frac{7}{2}}=0.23 \text { МПа. }
$$

Деформацію для куточка знаходять за двома фрормулами - формулою $\varepsilon_{\max }=s_{0} / 2 r_{c p}=1 / 2 \bar{r}$ і формулою, що враховує стискаючі деформації [7]:

$$
\varepsilon_{\max }=\frac{H}{R_{\Pi}+H} .
$$

Тоді

$$
\varepsilon_{\partial 1}=\frac{0.023}{0.1+0.023}+\frac{0.0012}{2 \cdot 0.0046}=0.317
$$

При $\varepsilon_{\partial 1}=0.317 \sigma_{\partial 1}=58.2 \cdot 0.317^{1,68}=0.84 \mathrm{M \Pi a}$.

При згинанні кута $q_{д о д}$ розраховуємо за фрормулою (7):

$$
q_{\text {до }}=\frac{2 \cdot 8.4 \cdot\left(10+0.12+\frac{7}{2}\right) \cdot 7}{(10+0.12)^{2}}=1.64 M \Pi a .
$$

Отриманий позитивний знак при $q_{\text {до }}$ відповідає умові, коли напруження, що діють в елементі оболонки, і напрям гідростатичного тиску збігаються.

3. Розрахунок сумарного потрібного тиску

Сумарний потрібний тиск для фоормоутворення бортів діафрагми :

$$
q_{\text {nom }}=q_{\text {гс } 11}+q_{\text {дод } 1}=0.96+0.23=1.19 \text { МПа } .
$$

4. Розрахунок пружинення і стоншування

Для діафрагми пружинення розраховують за фрормулою (11):

$$
\gamma=\frac{3 \cdot 108 \cdot 10^{6}}{72 \cdot 10^{9}} \cdot\left(\frac{0.005}{0.0012}+1\right) \cdot 90^{\circ}=2.1 .
$$

На підставі проведених досліджень і розрахунків було отримано ряд теоретичних даних про різні технологічні параметри процесу згинанняштампування. Обчислення за спрощеними формулами дозволило отримати попередні дані за такими параметрами процесу, як потрібний для формоутворення тиск, кут пружинения, можливі величини змін товщини заготовки. Проте цей розрахунок не дає повного уявлення про якість отримуваного виробу, особливо це стосується складних деталей типу опуклого 


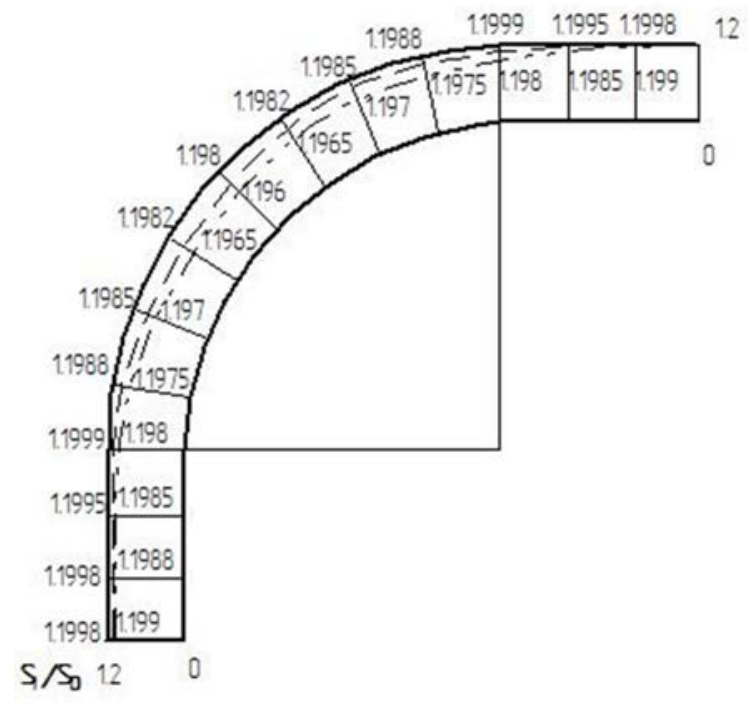

Рис. 15 - Графрік-схема зміни товщини заготовки в зоні згинання для діафрагми ------- - значення, отримані при моделюванні; ---.----.--- - експериментальні значення по Комарову А.Д. куточка, де відбувається складний процес фрормоутворення, усі чинники якого можна врахувати лише при проведенні дуже громіздких розрахунків. Побудова математичної моделі на основі MCE [2] дозволяє не лише визначити необхідні параметри процесу, але і розглянути процес формозміни на окремих його стадіях, визначити картину напружено-деформованого стану, виявити найбільш небезпечні зони згинанняштампування, зміну товщини матеріалу, а також простежити поведінку матеріалу після розвантаження. Усе це дає можливість оцінити якість

отримуваного виробу за визначеними параметрами процесу, а також одержати бажані результати шляхом варіювання початкових параметрів моделі.

Для того, щоб оцінити прийнятність використання такого методу для оцінювання якості деталі і визначення потрібних параметрів процеса, необхідно визначити збіжність результатів, що отримують при моделюванні 3 експериментальними даними, тобто оцінити отриману похибку даних. Оцінювання зміни товщини деталі проводять побудовою графріків-схем за експериментальними і змодельованими даними для двох деталей. На рисунку 15 зображено графрік-схему зміни товщини заготовки в процесі формоутворення в зоні згинання для діафрагми. Із схеми видно, що різниця в даних, отриманих експериментально, і змодельованих, $є$ невеликою. Для найбільш небезпечної ділянки зони згинання вона становить близько 1\%. Якість деталі значною мірою залежить від кута пружинення. Правильно вибраний коригувальний кут згинання для матриці дозволяє скоротити довідні роботи. Для оцінювання отриманих даних був побудований графік залежності кута пружинення від радіуса згинання (рисунок 16). У даному випадку були розглянуті як експериментальні і змодельовані дані, так і розрахункові. 3 графіка очевидно, що значення, отримані при проведенні експрес-обчислень за спрощеними формулами, значно відрізняються від даних, отриманих експериментально. Це пояснюється тим, що кут пружинення залежить не лише від характеристик, матеріалу заготовки і майбутньої геометрії деталі, але і значною мірою від тиску формоутворення і характеристик використовуваних еластичних середовищ, а ці параметри не враховують, при вичисленні за спрощеною формулою. При цьому порівняння змодельованих і експериментальних даних дали позитивні результати. 3 графріка видно, що середнє значення, на яке відрізняються величини кутів пружинення, становить від 1\% при невеликих радіусах згинанні до $3 \%$ при його збільшенні. 


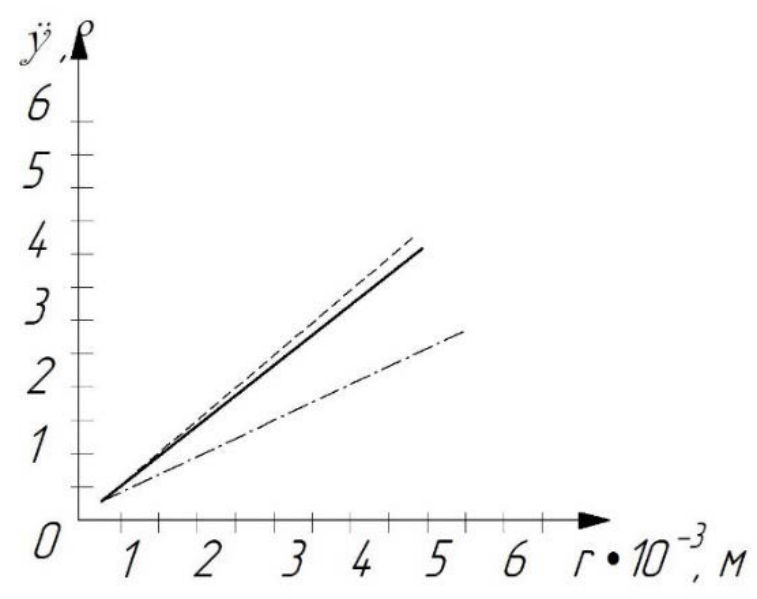

Рис. 16 - Графрік залежності кута пружинення від радіуса гнуття

- - - значення, отримані при моделюванні;

--- - експериментальні значення по Ісаченкову;

----.--- - дані вичислення за спрощеною фрормулою.

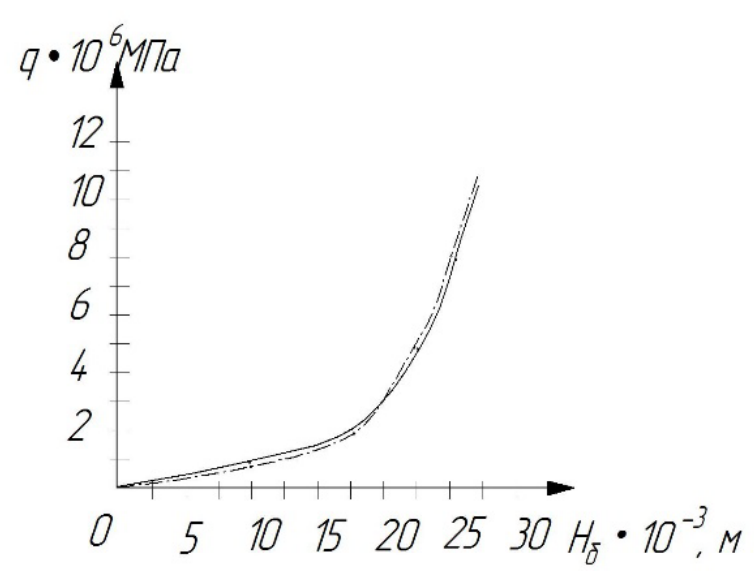

Рис. 17 - Графрік залежності тиску від висоти борта

------- - значення, отримані при

- моделюванні;

---.--- - експериментальні значення

по Комарову

Головним енергосиловим параметром процесу $€$ тиск, потрібний для здійснення операції формоутворення і отримання якісного виробу. Порівняння отриманих даних дало такіі результати:

для діафрагми:

$$
\frac{1-0.96}{0.96}=0.04=4 \% ；
$$

Отримані розбіжності в $3 . .4 \% €$ хорошим результатом і знаходяться в межах допустимих для теоретичних розрахунків похибок. Для порівняння 3 експериментальними даними був побудований графік залежності зміни тиску від висоти штампованого борта. Отримані результати дають розбіжності в $3 . .5$ \%, що видно з графріка (рис.17).

Таким чином, порівняння даних експерименту, розрахунку і моделювання дало розбіжності в середньому на 3-5\% за основними даними параметрами. Цей результат дозволяє свідчити про можливість подальшого вдосконалення і застосування моделювання на практиці.

\section{Висновок}

Проведений аналіз даних, отриманих на основі моделювання порівняно 3 експериментальними, дав позитивні результати, що дозволяє свідчити про можливість застосування і подальшого вдосконалення отриманих моделей на практиці. Застосування моделювання дає можливість не не лише визначити енергосилові параметри процесу, але і оцінити якість отримуваного виробу за окремими параметрами процесу. Найбільш доцільним $є$ застосування 
моделювання при виготовленні деталей, що мають складну фрорму, як деталі з опуклими, увігнутими, гранованими бортами або стінками. Розроблення процесу формоутворення для таких деталей пов'язано із складністю розрахунків потрібних параметрів процесу і неможливістю повністю оцінити майбутню якість отримуваного виробу. Моделювання дає можливість виявити найбільш небезпечні і навантажені ділянки, скоректувати параметри процесу для отримання необхідної фоорми виробу, що дозволяє уникнути застосування довідних робіт Проте саме моделювання складних процесів пов'язано 3 певними труднощами, такими, як великі витрати часу, потрібного на проведення якомога точнішого розрахунку, а також необхідність в наявності потужного устаткування. Одним із головних позитивних моментів, що свідчать на користь процесу моделювання на основі методу MCE, $є$ можливість застосування однієї моделі для моделювання типових або схожих виробів. Моделювання дозволяє звести кількість експериментів до мінімуму, що значно знижує статті витрат на матеріали. Особливо це важливо для дрібносерійного, досвідного виробництва і при впровадженні нових технологій. В цьому випадку моделювання допомагає виявити і скоректувати розрахункові теоретичні дані ще до проведення експерименту.

\section{Список літератури}

1. Ходырев, В.А. Применение полиуретана в листоштамповочном производстве / А.В. Ходырев. - Пермь: Политехника, 1973. - 143 с.

2. Исаченков, Е.И. Штамповка эластичными и жидкостными середами / Е.И. Исаченко. - М.: Машиностроение, 1976. - 386 с.

3. Комаров, А.Д. Опыт штамповки полиуретаном стальных деталей сложной формы / А.Д. Комаров // КШП: научно-технический журнал. - М.: 1991. № 8. - С. $11-19$.

4. Богоявленский К.Н. Изготовление заготовок и деталей пластическим десормированием / К.Н. Богоявленский. - Л.: Политехника, 1991. - 351с.

5. Попов Е.А. Технология и автоматизация листовой штамповки / Е.A. Попов - М.: МГТУ. 2003. - 257 с.

6. Комаров А.Д. Разработка и исследование процесса стесненного изгиба листовых заготовок эластичной средой / А.Д. Комаров // КШП: научнотехнический журнал. - М.: 1996. - № 10. - С.24 - 32.

7. Исаченков Е.И. Штамповка резиной и жидкостью / Е.И. Исаченко - М.: Машиностроение. 1967. - 367с.

8. Hallquist J. O. LS-DYNA theoretical manual / J. O. Hallquist. Livermore Software Technology Corporation: Livermore, CA, 2006. - 498 p.

\section{References}

1. Xodyrev, V.A. Pry`meneny`e poly`uretana v ly`stoshtampovochnom proy`zvodstve / A.V. Xodurev. - Perm`: Poly`texny`ka, 1973. - 143 c.

2. Y'sachenkov, E.Y'. Shtampovka эlasty 'chnыmy' y' zhy'dkostnыmy` seredamy` / E.Y`. Y`sachenko. - M.: Mashy`nostroeny`e, 1976. - 386 s. 
3. Komarov, A.D. Opыt shtampovky` poly uretanom stal`nыx detalej slozhnoj formы / A.D. Komarov // KShP: nauchno-texny`chesky`j zhurnal. - M.: 1991. - \# 8. S. $11-19$.

4. Bogoyavlensky`j K.N. Y`zgotovleny`e zagotovok y`detalej plasty`chesky`m deformy`rovany`em / K.N. Bogoyavlensky`j. - L.: Poly`texny`ka, 1991. - 351s.

5. Popov E.A. Texnology`ya y`avtomaty`zacy`ya ly`stovoj shtampovky` / E.A. Popov - M.: MGTU. 2003. - 257 s.

6. Komarov A.D. Razrabotka y` y`ssledovany`e processa stesnennogo y`zgy`ba ly`stovыx zagotovok эlasty`chnoj sredoj / A.D. Komarov // KShP: nauchnotexny`chesky`j zhurnal. - M.: 1996. - \# 10. - S.24-32.

7. Y`sachenkov E.Y`. Shtampovka rezy`noj y`zhy`dkost yu / E.Y`. Y`sachenko - M.: Mashy`nostroeny`e. 1967. - 367s.

8. Hallquist J. O. LS-DYNA theoretitsal manual / J. O. Hallquist. Livermore Software Technology Tsorporation: Livermore, TsA, 2006. - 498 p.

Надійшла до редакції 10.06.2019, розглянута на редколегії 12.06.2019

\section{Моделирование процесса штамповки диафрагмы из листовой заготовки эластичной средой}

Метод штамповки эластичным средой известен давно и везде, однако в пользу его дальнейшего применения и развития говорят разработки, которые позволяют интенсифицировать процесс штамповки эластичным инструментом. Среди таких направлений совершенствования, особенно перспективным является компьютерное моделирование процесса, которое позволяет определять энергосиловые параметры процесса, поведение материала на протяжении всего процесса, а также напряженно-деформированное состояние заготовки, что позволяет сократить время в дальнейшем при разработке процессов для типовых деталей, а также значительно снизить расходы материалов на проведение серий экспериментов, сократить трудоемкость и срок технологической подготовки производства. Именно этот метод, как наиболее приемлемый для усовершенствования процесса штамповки нынешней стадии развития отечественного производства, рассматриваемый в этой работе на примере гибки-формовки листового материала. Для решения задач формообразования, проводимых в этой работе, наиболее рациональным является применение вариационного метода или метода МКЭ. Оба эти метода обеспечивают получение достаточно точных результатов, однако, преимуществом МКЭ является его большая применимость в различных программных продуктах, таких как Nastran, Ansys, Katy и др., позволяет оптимизировать процесс получения данных сокращением времени расчета, а также наиболее оптимальной возможностью вносить изменения и корректировки в процесс без необходимости затрат время на ручной пересчет.

Ключевые слова: моделирование процесса штамповки, листовая заготовка, эластичная передающая среда, напряженно-деформированное состояние. 


\section{Simulation of Stamping Process of the Sheet Metal Diaphragm by Using Elastic Medium}

The method of stamping by an elastic medium is known for a long time and everywhere, and in favor of its further application, proves developments that allow the intensification of the stamping process by an elastic tool. Among these areas of improvement, the computer simulation of the process is particularly promising, which allows you to determine the energy-power parameters of the process, the behavior of the material throughout the process, as well as the stress-strain state of the workpiece, which allows you to shorten the time further in the development of processes for typical parts, as well as significantly reduce the cost of materials to conduct a series of experiments, reduce the complexity and time of technological preparation of production. It is this method as the most suitable for improving the stamping process at the current stage of development of domestic production, considered in this paper on the example of bending-molding sheet material. To solve the problems of forming, carried out in this work, the most rational is the use of the variation method or the FEM method. Both of these methods provide fairly accurate results, however, the advantage of FEM is its high applicability in various computer software products such as Nastran, Ansys, Katy, etc., which allows to optimize the process of obtaining data by reducing the calculation time, as well as the most optimal the ability to make changes and adjustments to the process without the need to spend time on manual recalculation.

Key words: modeling of stamping process, sheet blank, elastic medium, stress-strain state.

\section{Відомості про авторів:}

Застера Олександр Миколайович - к.т.н., доцент, професор кафедри технології виробництва літальних апаратів, Національний аерокосмічний університет ім. М.Є. Жуковського «Харківський авіаційний інститут», Харків, Україна, sastela@khai.edu

Трифонов Олег Валерійович - к.т.н., докторант кафедри технології виробництва літальних апаратів, Національний аерокосмічний університет ім. М.Є. Жуковського «Харківський авіаційний інститут», Харків, Україна, o.trifonov@khai.edu

Водолажський Віталій Петрович. - к.т.н., доцент, викладач, Харківський державний автодорожній коледж, Харків, Україна.

\section{About the authors:}

Zastela Oleksandr - PhD, Professor Assistant, Professor of the Airplane Manufacturing Department, National Aerospace University named after M. Ye. Zhukovsky "Kharkiv Aviation Institute", Kharkiv, Ukraine, sastela@khai.edu

Tryfonov Oleh - PhD, doctoral student of the Airplane Manufacturing Department, National Aerospace University named after M. Ye. Zhukovsky "Kharkiv Aviation Institute", Kharkiv, Ukraine, o.trifonov@khai.edu

Vodolazhskij Vitalij - PhD, Professor Assistant, teacher, Kharkiv State Automobile Road College, Kharkiv, Ukraine. 